\title{
Application of Problem Based Learning Approaches with Probing-Prompting Techniques to Improve Students' Adaptive Reasoning Capabilities
}

\author{
Nia Gardenia ${ }^{1}$, Tatang Herman ${ }^{2}$, Andri Rahadyan $^{3}$, Taufiqulloh Dahlan ${ }^{4}$ \\ $\left\{\right.$ tatangherman@upi.edu $\left.{ }^{2}\right\}$
}

\begin{abstract}
Departemen Pendidikan Matematika, Universitas Pendidikan Indonesia, Jl. Dr. Setiabudi No. 229, Bandung 40154, Indonesia ${ }^{1,2}$, Departemen Pendidikan Matematika, Universitas Indraprasta PGRI, Jl. Nangka No. 58C (TB. Simatupang), Tanjung Barat, Jagakarsa, RT.5/RW.5, Jakarta Selatan, DKI Jakarta 12530, Indonesia ${ }^{1,3}$, Departemen Pendidikan Matematika, Universitas Pasundan, Jl. Tamansari No. 6-8, Tamansari, Bandung Wetan, Kota Bandung, Jawa Barat 40116, Indonesia ${ }^{4}$
\end{abstract}

\begin{abstract}
This study aims to obtain an overview of the adaptive reasoning abilities of students who get mathematics learning through the Problem Based Learning approach with Probing-Prompting techniques compared to students who get conventional learning. The problems underlying this research include the adaptive reasoning ability of students in Indonesia is still low so innovation is needed in learning that can develop students' adaptive reasoning abilities. This research is a quasi-experimental research. Data obtained through research instruments in the form of tests and non-tests. Data analysis was carried out quantitatively. Quantitative analysis was performed by calculating the N-gaint using the normality test, and the Mann-Whitney U test. The results showed an increase in students' adaptive reasoning abilities in both groups, an increase in the adaptive reasoning abilities of students who obtained mathematics learning through the Problem Based Learning approach with Probing-Prompting is better than students who get conventional learning.
\end{abstract}

Keywords: Adaptive Reasoning Capabilities, Probing-Prompting, Problem Based Learning

\section{Introduction}

Mathematics learning developed in Indonesia today, not only requires students to be active in the learning process, but also requires students to process data provided by the teacher. The skills that support mathematics learning are not only the ability to count, but the abilities that develop the ability to reason. [1] Determination of reasoning ability as a goal and vision of mathematics learning is a necessary requirement for students. Students who have good reasoning ability will easily solve mathematical material and conversely students who have low mathematical punishment abilities will have difficulty understanding mathematical material [2]. Mathematical reasoning also requires the ability to sort out what is important and not important in solving problems and explain or provide reasons for solving [3].

Many studies show that early adolescents and adults have difficulty in solving problems that require punishment. Unreliable Indonesian students with mathematical punishment problems lead to Indonesian students' achievements in international renewal [4]. Correspondingly, as a whole are also grouped according to students who are cognitive, the score 
of students' abilities in punishment is still low [5]. [6] the results of a study conducted at one of the junior high schools in Pontianak explained about students who have low penalty skills (1) some students who use related problems, so the strategies used to solve problems are not appropriate; (2) adding basic knowledge before entering new knowledge that is often found during the problem solving process; and (3) students who still use inductive thinking in solving problems that use deductive or abstract thinking. [7] This was also revealed by another researcher at a junior high school in West Bandung Regency, who explained that from all categories of students' mathematical punishment abilities, indicators of mathematical manipulation were still not met properly. Based on the test results also that the achievement of mathematical manipulation indicators is only 44.

From some of the things that have been stated before, discussion about the ability to adapt punishment students who provide responses, provide answers to questions that are given, draw conclusions from the questions, find, find and use the pattern of a problem, and discuss any problems that are considered weak. The weak ability to adapt to students' punishment is a problem that needs to be overcome. In addition, most mathematics learning does not yet support the mathematical development of students who use the lecture method and memorize formulas [8]. One of the innovations in mathematics learning that can ask students to be active in the learning process encouraging students to use their adaptive reasoning skills is mathematics learning by using Problem Based Learning with Probing-Prompting techniques.

In PBL learning real learning will occur. Students who learn with PBL will be able to solve a problem using the knowledge they have or need the knowledge needed to solve the problem needed. Learning can improve student understanding related to interactions where concepts can be applied by integrating knowledge and simultaneous skills and applying them in relevant contexts [9].

To solve problems in learning Problem Based Learning is used Probing-Prompting techniques. Probing-Prompting Technique is a learning technique by means of the teacher giving advice that is guided and resolved related to the thought process that links each student's knowledge and experience with new knowledge being learned [10]. [11] Kissock and Iyortsuun explain about giving effective questions about other teaching methods, especially if they want to encourage students to think and reason, then Peterson suggests that by using effective questions, look for teachers to help and reason. Thus, learning through Problem Based Learning with Probing-Prompting techniques must be able to make students have a penalty ability that can be used in solving mathematical problems.

Based on the description above, it is necessary to further update about whether it is necessary to increase students' adaptive reasoning abilities in learning through Problem Based Learning Support with Probing-Prompting techniques. To answer these questions, the authors conducted research on the application of the Problem Based Learning approach with ProbingPrompting techniques to improve students' adaptive reasoning abilities.

\section{Experimental Method}

This study involved two groups of students namely the experimental group and the control group. The two groups are not chosen randomly, but the second group is chosen according to the class that already exists in the selected school, because it is not allowed to form a new group to get an experimental group and a truly homogeneous control group. Therefore, this research involves quasi research. 
Each group received different training in the learning process, except for the same material. In the experimental group learning is given by using Problem Based Learning with ProbingPrompting techniques while the control group is given conventional learning. This study uses a "pretest-posttest control group" research design or a pretest-posttest control group design. The following are published studies:

\section{$\mathrm{O} 1 \mathrm{X} \mathrm{O} 2$}

$\mathrm{O} 1 \mathrm{O} 2$

Information:

X: Learning through Problem Based Learning with Probing-Prompting techniques

O1: Pretest adaptive reasoning abilities

O2: Adaptive adaptive posttest ability.

\subsection{Populations and Sample}

The population in this study were all eighth grade students of SMP Negeri 3 Lembang, West Bandung Regency. Based on information from the school, eighth grade students of SMP Negeri 3 Lembang have diverse abilities, there are high, medium and low ability students. Based on the consideration that the eighth grade students are middle students who are in an education unit who are thought to have the ability to think semi-abstractly, then the eighth grade students of SMP Negeri 3 Lembang, West Bandung Regency are selected as the population in this study.

In SMP Negeri 3 Lembang, West Bandung Regency, there are nine classes at grade VIII, namely VIII-A, VIII-B, VIII-C, VIII-D, VIII-E, VIII-F, VIII-G, VIII-H, and VIII-I. In this study two groups are needed, namely the experimental and control groups so that of the nine classes are randomized to obtain two classes, namely classes VIII-B and VIII-C. The two classes were then randomized again to determine the experimental group and the control group, namely students of class VIII-B as the experimental group and students of class VIII-C as the control group.

\subsection{Research Variables}

There are 2 variables in this study, the dependent variable and the independent variable. The dependent variable in this study is the adaptive reasoning ability which is the goal of this study and the independent variable in this study is the Problem Based Learning approach with Probing-Prompting technique as a tool to improve adaptive reasoning abilities.

\section{Result and Discussion}

From the results of the analysis of the pretest data of students' adaptive reasoning abilities, the data of the experimental group and the control group came from populations that were not normally distributed using the Shapiro-Wilk normality test. Because the two data come from populations that are not normally distributed, then a similarity test of two averages (two parties) is conducted using the non-parametric Mann-Whitney U test, the significance value (2-tailed) is 0.633 , greater than 0.05 with a significance level of $5 \%$, meaning that $\mathrm{H}_{0}$ is accepted, meaning that the initial ability of adaptive reasoning students who get learning through the Problem Based Learning approach with Probing-Prompting techniques is significantly the same as students who get conventional learning. 
Table 1. Test for Similarity of Two Pretest Data Averages.

\begin{tabular}{lr}
\hline & \multicolumn{1}{c}{ Pretest } \\
\hline Mann-Whitney U & 556.000 \\
Wilcoxon W & 1117.000 \\
Z & -.477 \\
Asymp. Sig. (2-tailed) & .633 \\
\hline
\end{tabular}

The initial ability of students' adaptive reasoning in both groups has a small average. This shows that the adaptive reasoning ability of students in both groups before getting learning is low. This is natural because students are given tests of adaptive reasoning abilities whose material has never been presented to them.

Table 2. Descriptive Data Pretest Statistics.

\begin{tabular}{lrrrrrr}
\hline & N & Minimum & Maximum & Mean & Std. Deviation & Variance \\
\hline Pretest_Eksperimen & 33 & .00 & 13.00 & 5.5152 & 4.18421 & 17.508 \\
Pretest_Kontrol & 36 & .00 & 15.00 & 6.2222 & 5.87056 & 34.463 \\
Valid N (listwise) & 33 & & & & & \\
\hline
\end{tabular}

After learning through the Problem Based Learning approach with the Probing-Prompting technique applied to the experimental group and conventional learning applied to the control group, then both groups were given posttest adaptive reasoning abilities. To find out the increase in students' adaptive reasoning abilities after being given treatment, the data used are posttest data because both groups have the same initial adaptive reasoning abilities significantly. Based on the pretest and posttest data, the average posttest score is greater than the average pretest score, both for students who get learning through the Problem Based Learning approach with Probing-Prompting techniques and students who get conventional learning. This shows that there is an increase in the ability of adaptive reasoning in both groups.

Table 3. Test the Difference of Two Posttest Data Averages.

\begin{tabular}{lr}
\hline & \multicolumn{1}{c}{ Posttest } \\
\hline Mann-Whitney U & 455.500 \\
Wilcoxon W & 1121.500 \\
Z & -1.670 \\
Asymp. Sig. (2-tailed) & .095 \\
\hline
\end{tabular}


Posttest data analysis of the adaptive reasoning ability of the experimental group and the control group by statistical tests. The Shapiro-Wilk normality test was first performed to see data from the two groups whether they came from a normal distribution population or not. From the results of the normality test analysis, it was found that the posttest data of the experimental group came from populations that were normally distributed while the posttest data from the experimental groups came from populations that were not normally distributed. Because one group's posttest data came from populations that were not normally distributed, then Mann Whitney U's non-parametric test was performed. The results of the posttest data analysis with Mann Whitney U's non-parametric test with a significance level of 5\% were obtained that $\mathrm{H}_{0}$ was rejected, meaning an increase in ability Adaptive reasoning of students who get learning through the Problem Based Learning approach with Probing-Prompting techniques is significantly better than students who get conventional learning.

Table 4. Descriptive Statistics of Posttest Data.

\begin{tabular}{lrrrrrr}
\hline & N & Minimum & Maximum & Mean & Std. Deviation & Variance \\
\hline Posttest_Eksperimen & 33 & 5.00 & 100.00 & 51.7273 & 28.40695 & 806.955 \\
Posttest_Kontrol & 36 & 14.00 & 92.00 & 41.0833 & 20.39520 & 415.964 \\
Valid N (listwise) & 33 & & & & & \\
\hline
\end{tabular}

Based on the posttest data analysis results of the adaptive reasoning abilities of the students above, it can be concluded that increasing the adaptive reasoning ability of students who get learning through the Problem Based Learning approach with Probing-Prompting techniques is significantly better than increasing the adaptive reasoning ability of students who get conventional learning. However, seen from the average posttest score of the experimental group which amounted to 51.73 had not reached the minimum completeness criteria (KKM) of SMP Negeri 3 Lembang which was 65 . However, the increase was still very significant when compared with the control group with an average posttest score amounting to 41.08. Less than the maximum achievement of student learning outcomes is influenced by many factors, including students less accustomed to solving problems that they rarely get in learning, students are accustomed to working on problems that are routine and identical to the sample problems given in learning.

\section{Conclusion}

The results of the data analysis above indicate that the increase in the adaptive reasoning ability of students who get learning through the Problem Based Learning approach with Probing-Prompting techniques is significantly better than students who get conventional learning. This means that the Problem Based Learning approach with the Probing-Prompting technique contributes well to the students' adaptive reasoning abilities. Increased students' adaptive reasoning ability in the Problem Based Learning class with Probing-Prompting techniques caused by the Problem Based Learning approach has a learning process that challenges students to think and solve problems and investigate situations, develop questions, plan solutions, explore concepts and principles through the study of problems it faces. Besides 
that, it is supported by Probing-Prompting technique that presents questions that are guiding and exploring so that the thinking process occurs that links each student's knowledge and experience with new knowledge being learned.

Acknowledgments. The author would like to thank to student in SMP Negeri 3 Lembang and Prof. Dr. Tatang Herman, M. Ed for his ongoing support as a lecturer and as well as to friends of Mathematics Education Doctoral Program 2017 Indonesian Education University (UPI) above support and cooperation.

\section{References}

[1] M. Konita, M. Asikin, T. Sri, and N. Asih : Kemampuan Penalaran Matematis dalam Model Pembelajaran Connecting, Organizing, Reflecting. Extending, Prisma, vol. 2, pp. 611-615, (2019)

[2] Tukaryanto, P. Hendikawati, and S. Nugroho : Peningkatan Kemampuan Penalaran Matematik dan Percaya Diri Siswa Kelas X Melalui Model Discovery Learning. Prism. Pros. Semin. Nas. Mat., vol. 1, pp. 810-813, (2018)

[3] D. R. Kusumawardani, Wardono, and K. Kartono : Pentingnya Penalaran Matematika dalam Meningkatkan Kemampuan Literasi Matematika. Prism. Pros. Semin. Nas. Mat., vol. 1, pp. 588-595, (2018)

[4] R. Johar, S. Yusniarti, and Saminan : The analysis of proportional reasoning problem in the Indonesian mathematics textbook for the junior high school : J. Math. Educ., vol. 9, no. 1, pp. 55-68, (2018)

[5] C. S. Ayal, Y. S. Kusuma, J. Sabandar, and J. A. Dahlan : The Enhancement of Mathematical Reasoning Ability of Junior High School Students by Applying Mind Mapping Strategy. J. Educ. Pract., vol. 7, no. 25, pp. 50-58, (2016)

[6] T. Indriani, A. Hartoyo, and D. Astuti : Kemampuan penalaran adaptif siswa dalam memecahkan masalah kelas viii smp pontianak. J. Pendidik. dan Pembelajaran Khatulistiwa, vol. 6, no. 2, pp. 1-12, (2017)

[7] S. Tri Roro, M. Rippi, and S. Eka : Analisis Kemampuan Penalaran Matematis Siswa SMP Pada Materi Seegitiga dan Segiempat. J. Kaji. Pembelajaran Mat., vol. 2, no. April, pp. 9-13, (2018)

[8] Y. Wicaksana : Penalaran Matematis dan Kerja Keras Siswa Pembelajaran Matematika Berorientasi Teori APOS Berbantuan Permainan Monopoli in Seminar Nasional Matematika X Universitas Negeri Semarang, pp. 305-311 (2018)

[9] Wardono, S. B. Waluya, Kartono, Mulyono, and S. Mariani : Literasi Matematika Siswa SMP pada Pembelajaran Problem Based Learning Realistik Edmodo. Prisma, vol. 1, pp. 477-497, (2018)

[10] Y. Kurniasari and Susanah : Penerapan Teknik Pembelajaran Probing Prompting Untuk Mengetahui Kemampuan Penalaran Matematika Siswa Kelas 7 G Di Smpn 1 Rejoso, Unesa, (2013)

[11] N. Y. Rustaman and A. Rustaman : Peranan Pertanyaan Produktif dalam Pengembangan KPS dan LKS, Bandung, (2010) 